\title{
An experimental test of the interfering-response theory of extinction ${ }^{1}$
}

\author{
MELVIN H. MARX \\ UNIVERSITY OF MISSOURI, COLUMBIA
}

\begin{abstract}
Three experiments are reported in which laboratory rats were allowed to make a barpress response incompatible with the reinforced barpress response. This opportunity to make an interfering response did not generally reduce resistance to extinction, and the interference theory of extinction was therefore not supported.
\end{abstract}

This paper reports research designed to test the proposition that the opportunity to make a response incompatible with a learned response will reduce the resistance to extinction of the learned response. This proposition was drawn as an implication from the interfering-response theory of extinction (e.g., Guthrie, 1935, Estes, 1950, 1958), according to which extinction occurs because of the replacement of the learned response by competing responses.

\section{Experiment I}

The Ss were 14 young female hooded rats, maintained on a $23 \mathrm{~h}$ feeding schedule. The apparatus was a set of eight controlled-operant conditioning boxes, previously described in detail (Marx et al, 1965). The Ss were trained to barpress on a CI 60/60 (controlledinterval) program in which the bar retracted at press, or automatically after $60 \mathrm{sec}$ if not pressed, and reappeared in either case after a $60 \mathrm{sec}$ intertrial interval. The reinforcement was .1 ml of $32 \%$ sucrose in water. After three days of magazine training, 20 barpress training trials were given daily for 10 days. During extinction half of the Ss were tested with a second bar, in addition to the primary bar on which they had been trained; pressing of this secondary bar defined the interfering response. The bar(s) were automatically presented for $30 \mathrm{sec}$ and retracted for 10 sec for 20 trials on the test day. Repeated barpresses could then be made without retracting the bar(s) or operating the magazine.

The results were that the group with two bars to press in extinction made reliably fewer responses to the primary bar $(t=3.12, d f=12, p<.01)$, but there was not a statistically reliable difference in total barpress output $(t=1.48, \mathrm{df}=12, \mathrm{p}>.05)$.

\section{Experiment 2}

This experiment replicated the first one with the addition of a group of Ss which were trained with the secondary bar present. These Ss were then split in extinction, half tested with both bars and half with only the primary bar. The Ss were young female hooded rats maintained on a $23.5 \mathrm{~h}$ water-drinking schedule. The apparatus and experimental procedure were essentially as in Experiment 1 except that the reinforcement was .1 $\mathrm{ml}$ of water, and in extinction
$1030 \mathrm{sec}$ presentations of the bar(s) were given (the bar(s) remaining for that period regardless of pressing) with a $30 \mathrm{sec}$ intertrial interval. The two bars were presented and retracted together. Operation of the bars and the magazine in training was programmed by the primary bar.

Very slight and entirely nonreliable differences in primary barpresses occurred in extinction for the four groups of this experiment. This was true of both number of barpresses and first barpress latency on each trial. The frequencies of the secondary barpresses are shown in Fig. 1 for the groups which had this bar available in training and/or test. These data indicate that rather than replacing the primary barpress the secondary barpress itself showed extinction during training as well as test. Moreover, a number of correlations (e.g., secondary barpresses in acquisition and in extinction; secondary barpresses in acquisition and primary barpresses in extinction; and secondary barpresses in extinction and primary barpresses in extinction) all proved to be low positive and nonreliable. Experiment 3

The Ss were 32 young female albino rats, maintained on a $23 \mathrm{~h}$ feeding schedule. The apparatus and experimental design were essentially the same as in Experiment 2 except that $.1 \mathrm{ml}$ of sucrose in water was used as reinforcer, 50 extinction trials were administered in the same manner as training trials, and the feeding magazine was located by the secondary rather than the primary bar. The latter arrangement was intended to encourage the making of secondary barpresses.

No reliable group differences in primary barpress latencies or trials to extinction (to five consecutive failures to respond) were found. The correlations computed as in Experiment 2 were again low positive and nonreliable.

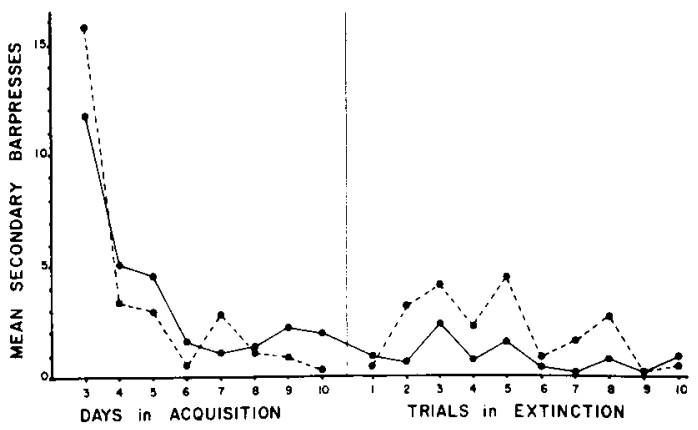

Fig. 1. Mean secondary barpresses by groups with bar available only in acquisition or extinction (broken lines) and both in acquisition and extinction (solid line). 


\section{Discussion}

Although there was some slight suggestion of support for the proposition under test in Experiment 1, which showed more primary barpresses in extinction for the group without the secondary bar, this result was not replicated in either of the other two experiments. Moreover, the data plotted in Fig. 1 suggest that under the present experimental conditions the opportunity to make a potentially interfering response resulted in the extinction of that response rather than its replacing of the learned response.

These results offer little support for the interference theory of extinction. Although the potentially interfering response did occur, it did not reliably reduce resistance to extinction. Repetition of the present experimental design using a potential competing response clearly different from the learned response should be attempted to reduce the degree of interresponse generalization. Nevertheless, the significance of these generally negative results, while necessarily limited on logical grounds, is enhanced by the relative paucity of concrete experimental tests of the interference theory (cf. Marx, 1963). Furthermore, the present barpress results are entirely consistent with the recently reported failure of runway retracing to reduce resistance to extinction (Marx, 1967a, 1967b) and so may be viewed as raising additional questions concerning the interference theory of extinction.

\section{References}

ESTES, W. K. Effects of competing reactions on the conditioning curve for bar pressing. J. exp. Psychol., 1950, 40, 200-205.

ESTES, W. K. Stimulus-response theory of drive. In Jones, M. R. (Ed.), Nebraska Symposium on Motivation. Lincoln: University of Nebraska Press, 1958.

GUTHRIE, E. R. The psychology of learning. New York: Harper, 1935. MARX, M. H. The need for more specific formulations of the "competing response" interpretation of extinction. Psychol. Rep., 1963, 12, 729-730.

MARX, M. H. Resistance to extinction as a function of delay of reinforcement and the opportunity to retrace in the runway. Psychon. Sci., 1967a, 8, 287-288.

MARX, M. H. Increased resistance to extinction as a function of the opportunity to retrace in the runway. Psychon. Sci., 1967b, 9, 397-398.

MARX, M. H., TOMBAUGH, T. N., HATCH, R. S., \& TOMBAUGH, Jo W. Controlled operant conditioning boxes with discrete-trial programming for multiple experimental use. Percept. mot. Skills, 1965 , $21,247-254$.

\section{Note}

1. This research was supported in part by Grant HD-00895 from the National Institute of Child Health and Human Development, and by USPHS Research Career Award 1-K6-MH-22, 023 from the National Institute of Mental Health. 